\title{
LA ÉTICA DE LA VIOLENCIA: \\ IDENTIDAD Y SILENCIO EN 1492
}

POR

IRIS M. ZavalA

Universidad de Utrecht

Hace casi un siglo, Federico Nietzsche escribió que la ética misma constituía el vehículo ideológico para legitimar la opresión. Nos recordaba a su vez el conjunto de las estructuras lógico-lingüísticas de la metafísica para crear el sistema de ficciones con las que se articula el nexo conocimiento-interés de la civilización occidental. Y, no menos importante, la actividad simbólica mediante la cual se elabora el sometimiento a autoridades divinas y humanas para dominar la naturaleza. ${ }^{1}$ Querría re-acentuar o re-evaluar la proyección ética del pensamiento nietzscheano y combinarlo con algunas reflexiones bajtinianas sobre la ética y el silencio, para sugerir así una comprensión de los hechos históricos ocurridos entre 1492-1493. Se ubica en esta fecha una relación fetichista, que hace que el primer texto cultural sobre el Nuevo Mundo sea, no la verdad convertida en fábula, sino la fábula convertida en verdad, para configurar una sociedad fundada sobre el dominio y la división entre amos y esclavos.

Dicho de otro modo, como parte del etnocentrismo occidental es el doble paso en el cumplimiento del programa ecuménico de la cultura de Occidente. Retomando esta línea de pensamiento y re-acentuando las reflexiones nietzscheanas, los textos culturales colombinos nos presentan en su origen al creador de símbolos y la reducción general de la realidad a fábula, que luego se va anquilosando convertida en habitus, y que corresponde al proceso de progresiva afirmación y despliegue de la "razón", que quiere funcionalizarlo todo, de modo definido, para sus propias exigencias productivo-organizativas.

Partimos pues de la convicción que no hay hecho que no sea producto de un acto de interpretación (universalidad propuesta ya por Nietzsche, Marx y Freud), y que ésta sirve a menudo para distribuir roles y posiciones dentro de la sociedad. Las Cartas, el Diario y las famosas Relaciones (en cuyas diferencias no hemos de entrar ahora, pues hemos de tomar el conjunto como texto cultural o texto de cultura) serían un ejemplo de la peculiar ficción del mundo del símbolo. Hemos de relacionar la situación contextual específica de estas fechas con lo que podríamos llamar la explotación moderna capitalista de extensos grupos de identidades colectivas; es decir, un orden social y religioso jerárquico tradicional que se apoya en el logos occidental y en la construcción del nuevo sujeto occidental para justificar la opresión y el 'altericidio' del Nuevo Mundo. El mundo de lo "dado" hace

\footnotetext{
${ }^{1}$ Aludo en particular a La voluntad de poder.
} 
concebir el lenguaje como evento inaugural de un mundo histórico y el alcance ontológicamente fundante del lenguaje. Me parece necesario recordar que empleo el término "moderno" como una metonimia espacial del expansionismo europeo, y "racional" como valor universal que permite articular una representación fija de la construcción de la identidad colonial. Es evidente que lo occidental es inseparable del desarrollo de la razón y del humanismo como prácticas hegemónicas, y que la ficción o narrativa de la modernidad constituye un mundo de simulacros y un reino de representaciones fraudulentas. ${ }^{2}$

Invoco aquí el resbaloso concepto de "modernidad" que se emplea desde el siglo $\mathrm{V}$, y se re-acentúa y re-valora después de 1492 y durante el Renacimiento, para connotar y denotar la re-escritura racionalista y capitalista de la utopía social eurocéntrica y el programa de desarrollo lineal, al mismo tiempo que los fundamentos ontológicos del colonialismo. El fin de siglo de esta modernidad florece en Europa con y dentro de un discurso de triunfalismo y una ética y una cultura orientada hacia fines lucrativos. En este contexto situacional, la coyuntura de 1492 apunta hacia un gigantesco espacio conflictivo de memorias en pugna.

El violento tenor de la vida en Europa (parafraseando una conocida frase de Huizinga), y más específicamente de la corona de España, que acababa de vencer el último baluarte árabe y que había expulsado a los judíos del cuerpo del estado y del cuerpo místico de la Iglesia, es el lugar que connota y condensa todas las imágenes y las representaciones, y todas las axiologías del signo, que se entremezclan con el poderoso nacionalismo emergente de la monarquía castellana y la Iglesia triunfante.

En este contexto de reforzamiento de un moderno estado-nación teocrático (posmulticultural y posmultisocial), la transmisión de la "verdad" podría clasificarse (desde nuestra óptica actual), como discurso político. $\mathrm{O}$, recordando el análisis desmistificador del lenguaje del joven Marx, que establece relaciones entre dinero y concepto:

¿Qué es entonces la verdad? Una hueste en movimiento de metáforas, metonimias, antropomorfismos, en resumidas cuentas, una suma de relaciones humanas que han sido realzadas, extrapoladas y adornadas poética y retóricamente [...] (citado en Nietzsche 1990: 11).

Si re-contextualizamos a Marx y a Nietzsche, la verdad no es más que una mentira colectiva y su represión, y continuando esta línea de pensamiento de crítica del lenguaje y sus tropos, todo es ficción, lo que equivale a decir, que todo es 'invento'. Pero, extendiendo algo más la alegoría, el empleo de la lengua y su uso performativo revelan ciertos rasgos de distorsión hacia lo mitológico (apoyándome en el concepto de Barthes 1957). Las referencias de sentido a palabras tales como "sangre", "cristiandad", "infiel o idólatra" se re-acentúan en otros contextos, y despiertan así connotaciones y denotaciones inconscientes. ${ }^{3}$

\footnotetext{
${ }^{2}$ Me apoyo en el prólogo de M. Foucault al libro de Pierre Klossowski, The Baphomet (Nueva York: Eridanos Library, 1988), que Simon During (1990: 249) cita en otra dirección.

${ }^{3} \mathrm{Me}$ apoyo en el conjunto de trabajos compilados por Ruth Wodak, editora 1989, sobre el fascismo y el nazismo, analizados desde los supuestos de "lingúística crítica". Abundan los análisis sobre el discurso autoritario; en mi encuadre empleo el importante concepto del análisis del discurso sobre los estereotipos. En la coyuntura que nos ocupa, los estereotipos estaban pluridirigidos hacia los rasgos sociales, sexuales, físicos, etc.
} 
El lenguaje se carga emocionalmente para crear imágenes-enemigas, y cobra sentido dentro de la tradición binarista occidental, para reforzar juicios de valor específicos. En este momento relacional, el significado se constituye a partir de la sedimentación histórica de una serie de tradiciones que tienen como denominador común justificar la superioridad mediante la re-acentuación de mitos y el irracionalismo del Otro para fortificar su superioridad moral y social. Esta moderna ficción o narrativa sobre el mundo es una parcialidad tomada por totalidad, y uno de sus rasgos más sobresalientes es el estrecho lazo que se establece entre conocimiento e interés; el interés se constituye a través de una óptica ptolemaica que tiende a monologizar y totalizar lo real; es decir, una fábula devenida en verdad. Tal óptica de validez universal (y religiosa) también se proyecta mediante una serie de exclusiones - la naturaleza, los habitantes aborígenes - pero tampoco podemos dejar de lado las construcciones genéricas. ${ }^{4}$

En este contexto situacional, esta "modernidad" (nuevo mundo versus viejo mundo) se justifica y valida en varios campos, y madura sus redes de sentidos. ${ }^{5}$ En el fondo de sus pretensiones universales podemos percibir la relación entre los intereses económicos, el pensamiento filosófico, el saber científico y la economía libidinal (término que tomo de Lyotard) para proyectar una forma nueva de identidad. Cuanto permanece afuera de estos márgenes es ajeno, no pertenece a la identidad dominante; la concretización del logos occidental en esta juntura parte de una realidad económica precisa: el desarrollo del expansionismo y del capitalismo occidental, apoyados por la "racionalización" o "razón instrumental" como un proyecto de dominio. Éstos parecerían ser los eslabones que articulan (en el sentido gramsciano) un campo de posiciones heterogéneas y hasta discursos contradictorios.

Lo que posteriormente se conocerá como "razón instrumental" después de Max Weber, se justifica en esta juntura a partir de una superioridad racional o eugénica, formas más altas de civilización e imperativos ético-teológicos, que permiten la subordinación racional de sociedades y culturas entendidas como inferiores. Lo que constituye aquí la violencia de la modernidad es, simultáneamente, una de sus mayores crisis, ya que el llamado 'descubrimiento' y la conquista son el punto nodal de intersección entre fuerzas contradictorias (Las Casas sería el punto opuesto). Así pues, estos textos fundacionales deben leerse como un hecho que no podemos no saber (what we can not know, por emplear una conocida frase de William James).

Querría ahora sugerir una combinación de métodos teóricos para replantear el "encuentro" en el contexto de lo que denominaré (en sentido amplio) cronotopo carnavalesco, regido por el hors-text o lo-fuera-del texto, de la práctica inquisitorial, que parangona los enunciados o géneros discursivos empleados por Colón: las cartas y el Diario (desconocido hasta que las Casas lo publicó). La circulación de los discursos

\footnotetext{
${ }^{4}$ En otro momento he desarrollado el problema de las construcciones genéricas elaboradas en las cartas de Vespucio, véase Zavala 1991, 1993. También L. Montrose 1991 sugiere que las construcciones genéricas se exportaron al nuevo mundo. Véase asimismo el libro de Margarita Zamora sobre Colón.

${ }^{5}$ Mi empleo del término "moderno" no se usa en el sentido que le confieren ni Jacob Burkhardt, ni el "nuevo historicismo" (por ejemplo Stephen Greenblatt). Aludo más bien al desarrollo específico de un complejo que incorpora la tecnología, la explotación y el capitalismo.
} 
sociales, en esta coyuntura, viene determinado por la naturaleza específica de una esfera de comunicación que cruza fronteras con la variedad de discursos legales, políticos y religiosos (tanto orales como escritos). De la tradición escrita, el uso que hace Colón de las cartas y del repertorio de formas genéricas medievales (entre otras la carnavalización), se re-acentúa con el trasfondo de algunas ideas motrices y sus clisés básicos. Hemos de recordar que lo que articulaba el discurso hegemónico de la Corona en 1492 eran la intolerancia religiosa y el triunfalismo de la mentalidad teológica, obsesionada con la oposición binaria entre los pecados y las virtudes. Los interlocutores de Colón eran conscientes de este discurso, que aparece como trazo presupuesto silenciado en los textos, presuposición que, desde luego, regía la selección del lenguaje empleado (y de los géneros discursivos). Nadie podía no saber las implicaciones de cada registro.

Con este encuadre de lo anterior y fuera del texto que circula en los discursos sociales, propongo que el objeto ("Indias", "indios") se había articulado, disputado y elucidado, a la par que evaluado (empleando a Bajtin en otro sentido); se puede decir que en los textos colombinos, el intertexto, el co-texto, y el architexto articulan de manera implícita los temblores y residuos de la ideología triunfalista dominante en el horizonte axiológico. Colón era, en este sentido preciso, tanto el "Adán bíblico", como el participante activo en un vasto diálogo, que incluye una gama de valoraciones en la cadena comunicativa. Sus enunciados permiten observar la huella de lo reprimido, el juego de connotaciones, la influencia refractada de sus destinatarios; se puede reconocer, bajo el trayecto de lo inscrito, el camino y el trazo de lo no dicho, la suma de desvíos en la palabra escogida que muestra las huellas de las presiones culturales.

En efecto, los enunciados colombinos se dirigen no sólo a su propio objeto, sino al enunciado de otros, tomando en cuenta las posibles respuestas. La epístola o carta (una especie de carta hablada) tiene la particularidad de su "adresividad" (en términos bajtinianos), y de una fluidez de fronteras para inscribir el sistema semiótico ideológico de la colectividad; se podría admitir que la carnavalización ayudó a desplazar estos enunciados hacia el deseo y las dislocaciones hacia las formas estereotipadas del abuso ritual del Otro. La carnavalización se suplementa con las oposiciones binarias simétricas de la mentalidad escolástica.

El cronotopo de la carnavalización se apropia aquí como eslabón entre la ideología oficial y la no-oficial, y el cuerpo grotesco (metáfora epistémica), nos permite comprender la dinámica del contraste entre dos visiones distintas del mundo sobre un mismo acontecimiento. Por una parte tenemos el cuerpo individualizado y auto-suficiente del conquistador, y las protuberacias fragmentadas que se le adscriben a las nuevas identidades, a través de ideologemas éticos que se re-acentúan en esta coyuntura, que combinan juicios de valor del horizonte ideológico, que van formando a su vez el discurso del imperialismo. Las protuberacias corporales son representaciones sinecdóquicas estereotipadas de las ideologías en circulación (políticas, religiosas, legales, científicas), que legitiman la destrucción y/o asimilación del "mal" personificado en el Otro. En este sentido muy preciso, las cartas colombinas son dialógicas, en relación semántica (e ideológica) con un "tercero" o superoyente participante silente: la evaluación del panóptico inquisitorial. Este "tercero" está prefigurado, mediante la operación moral e ideológica de intentar mantener la coherencia y propiedad del sujeto ideológico: el "tercero" inquisitorial cierra 
el vacío enunciativo mediante su proyección moral. No obstante, mi lectura dialógica contrasta con la intención autorial de enunciados monológicos que reprimen y silencian al Otro.

Antes de poder determinar el horizonte ideológico, debemos retomar algunas de las sugerencias bajtinianas en torno a las formas de estratificación ideológica, la ambivalencia, la homologación, la connivencia recíproca, el camuflaje, la fisonomía imprecisa y las derivaciones dudosas. ${ }^{6}$ En el texto cultural que nos ocupa, me atrevería a proponer que los géneros discursivos ( $\mathrm{y}$ me limito a las cartas y al diario de Colón, y a las cartas de Vespuccio), incorporan ideologías en proceso de formación en la práctica social como material de producción, en lugar de las ideologías oficiales ya configuradas (remito a El método formal [1928] 1994). ${ }^{7}$ La retórica colombina nos permite percibir las formaciones discursivas en proceso de constituirse, en suplementos que permiten identificar los cuerpos desnudos y el valor económico (el oro)

Si emprendemos una lectura dialógica de los textos culturales colombinos, podremos reconstruir lo decible y 'escribible', y al mismo tiempo podremos oír el rumor de la formación de discursos sobre el Otro, en su variedad del estereotipo y lo tópico. Todo giro se activa, y este texto cultural nos hace escuchar las múltiples maneras de hablar de un estado de sociedad que determina las normas de lo aceptable, lo legitimable y lo justificable. Son enunciados construidos a partir de migraciones del orden dóxico, de la opinión pública, de los conocimientos disciplinarios, de las fraseologías triunfalistas, de los lemas políticos, las grandes doctrinas y hasta las utopías, incorporadas todas como visiones del mundo y saberes religiosos y políticos. Podemos escuchar el eco de todos los elementos pertenecientes al discurso de predicación (autoridades divinas, sentencias, interpelaciones, exempla), que remiten a un conjunto de principios de la moral cristiana, y la reproduce en los textos en su función metonímica a nivel mítico o tópico. Todo ello está semiotizado en los discursos que incorpora y re-acentúa, en los símbolos y las formas culturales que tematizan lo real, pasado por el imaginario.

Retomemos la descripición sobre la ideología de Medvedev/Bajtin en El método formal. Todo producto ideológico (ideologema) forma parte del material de la realidad social, es un aspecto del horizonte ideológico materializado. Todo producto ideológico se plasma en el material objetivamente accesible: "en la palabra, en el sonido, en el gesto, en la combinación de volúmenes, líneas, colores, cuerpos vivientes, etc. [...] La comunicación es aquel medio en el que un fenómenos ideológico cobra por primera vez su ser específico, su carácter sígnico" (14-15). Se debe concluir que el significado que se le otorga a las palabras es ideológico, como respuesta a un signo, ya que todo es objeto de intercambio social. En esta relación tan someramente explicada, se deben confrontar dos problemas: primero, el de las formas particulares del material ideológico organizado en cuanto material significante; segundo, el de las formas particulares de la comunicación social que lleva a cabo esta significación. En términos bajtinianos, el significado se construye mediante conexiones sociales, en la interacción que se establece entre muchas personas; la realidad

\footnotetext{
${ }^{6}$ Estudiadas por Augusto Ponzio, véase 1982.

${ }^{7}$ Véase el excelente artículo-prólogo de Amalia Rodríguez Monroy, "De la palabra y su fiesta de resurrección. Problemas de una poética formal”, a la traducción de este texto.
} 
material concreta y la comprensión de un producto ideológico presuponen vínculos sociales. Y, puesto que todo signo ideológico cumple distintas funciones en la unidad de la vida social, las conexiones que hacen posible la comprensión son variadas y múltiples.

El medio ideológico (y sigo parafraseando el texto bajtiniano) que en sentido amplio podemos definir como "cultura", es la conciencia social de una colectividad específica, conciencia realizada, materializada, externamente expresada. El medio de la conciencia es ideológico y se da en un devenir, en el seno de contradicciones que se superan y vuelven a surgir; este medio es una totalidad, que incluye la ciencia, las artes, la ética y otras ideologías, en una síntesis. Los modales, las ceremonias, los signos convencionales de comunicación se determinan por el medio ideológico, y a su vez lo determinan, reflejando y refractando sólo indirectamente la existencia socioeconómica y natural (27). Este medio es fundamental, puesto que además de la creación puramente ideológica, toda una serie de actividades sociales, tales como la política, la propaganda cultural y religiosa y la educación, colaboran en su desarrollo. Hasta aquí las observaciones de Medvedev/Bajtin sobre la ideología. Pasemos ahora a ver cómo se marca en el signo.

El contenido de los géneros de enunciado - de los cuales la literatura es sólo uno de sus discursos- refleja y refracta los reflejos y refracciones de otras esferas ideológicas. El texto refleja en su contenido (asunto, tema) aquel horizonte ideológico en su totalidad cuya parte él mismo es. Pero los contenidos éticos y epistemológicos no se toman del sistema de conocimíento ni del ethos, sino directamente del proceso generativo; por ello, muchas veces ha anticipado los ideologemas filosóficos y éticos; la literatura penetra en el laboratorio social de sus formaciones y construcciones. Se podría deducir que los textos representan el flujo aún inarticulado de una ideología en proceso de formación. El bien, la maldad, la verdad, el crimen, el deber, la muerte, el amor, la victoria son valores ideológicos sin los cuales no puede haber ni argumento ni asunto, tema o motivo. Todos son distintos, dependiendo del horizonte ideológico de la clase social (a los que añadiremos género sexual y etnia) de la cual provienen. Las diferencias entre los argumentos indican diferencias de valores.

Para finalizar esta extensa digresión sobre el medio ideológico y su refractación textual, debemos recordar que si el lenguaje es un sistema de evaluaciones sociales, cuando los ideologemas se inscriben en el texto, se convierten en elemento estructural de la totalidad artística. Al formar parte de los textos, transfieren hacia la estructura toda su significación y seriedad, y su plena responsabilidad ideologica.

Si retomamos los textos colombinos, el desplazamiento de los ideologemas extratextuales, que se precisan desde la perspectiva de una hegemonía socio-discursiva, de un bloque socio-histórico, orientan ideológicamente la constitución de su discurso, que a su vez, es interdiscursivo. Es decir, se oye en sus textos el rumor e influencia recíproca de los diferentes discursos que circulan en el contexto social (a los cuales ya he aludido), incluyendo los que se seleccionan para ser reproducidos en sus textos (lo que Edmond Cros 1988 llama ideosema), o lo ideológico textualizado. Es decir lo ideológico y lo semiótico en su potencial discursivo y de textualización. En los textos colombinos los ideologemas son portadores de evaluaciones éticas, y representan el fluir de la ideología emergente o en formación del capitalismo y del logos (eurocentrismo y racismo). Esta interdiscursividad permite adscribir a las representaciones del Nuevo Mundo los valores ideológicos de bien, mal, victoria, deber, crimen y verdad. Este fluir de referentes nos permite identificar las 
instituciones que parangonan (en el sentido derrideano) el marco de los enunciados colombinos: la Iglesia y la Corona. Pero, además, sugiero que lo que he identificado como cronotopo carnavalesco es uno de los mecanismos ideológicos de estado (en el sentido que le da Louis Althusser), que parangonizan el discurso, reproduciendo el clima ideológico de Guerra Justa o Guerra contra el Infiel, al mismo tiempo que connotan y condensan los triunfos colectivos contra el mal. La seriedad retórica rigurosa y "científica" del discurso colombino ejerció una poderosa influencia en el tono de fanatismo y espíritu categórico de las cartas. Esta complejidad de estructuras y mecanismos debe considerarse como la totalidad social completa e históricamente determinada que le confiere sentido.

El horizonte ideológico que regula la semiosis se constituye a partir de dos prácticas discursivas (el Carnaval y la Inquisición). Esta última, como se sabe, fue la plataforma religiosa y de estado para la persecución de los Cristianos nuevos, y se institucionalizó en 1480; un año después ya habían sido quemadas en la hoguera 6 personas en auto de fe. En los primeros ocho años - y sigo a Andrés Bernáldez, cronista y párroco de Los Palacios, en Andalucía - se había llevado a la hoguera más de 700 personas y castigado a más de 5,000 (Kamen 1965: 46). En 1492 se encendió el fervor religioso después de la re-conquista de Granada y la expulsión de los judíos; nadie, en esta coyuntura, podía no saber (por retomar a James) cuánto estaba ocurriendo, menos aún Colón que estaba en el epicentro del ciclón de la Guerra Santa.

La identificación social específica de la cristiandad post-1492 llevó a identificarse desde un punto de vista de dogmatismo religioso (después de la expulsión de los judíos y la creación de guetos de conversos). En este encuadre, podemos suponer que los enunciados parten de esta formación discursiva, que su práctica textual se articula partir de la función carnavalesca como "interpretante" de la Inquisición, y que la Inquisición funciona como interpretante del carnaval. ${ }^{8}$ Como forma de enunciado, este género de cartas anunciaba novedades, $\mathrm{y}$ también podrían leerse como pre-formas latentes periodísticas o de papel menudo, cuya producción de sentido como estructuras mediadoras, formaba parte del contexto sociopolítico. En los textos culturales colombinos se plantea, de una manera particular el problema de la interpelación ideológica: sus enunciados remiten a varias prácticas sociales: el funcionamiento de los mecanismos ideológicos del Estado, a procesos económicos y sociales (la creación de rutas comerciales, la expansión de fronteras), y a situaciones conflictivas (la Guerra contra el Infiel, el desarrollo de la monarquía castellana, la institucionalización de la Inquisición, la persecución). Su práctica textual carnavalizada dimana de la amenaza que estos "bárbaros" e "infieles" creaban en el nuevo orden mundial. La monología y el silencio son aquí estrategias para impedir una posible confrontación y salvaguardar los valores cristianos: la formación ideológica a la cual nos hemos referido determina la formación discursiva conflictiva y contradictoria y el silencio de los discursos que planteasen intereses sociales contradictorios y divergentes. El cronotopo del carnaval se convierte aquí en un significador sobredeterminado, una especie de esencialismo estratégico para apropiarse el poder. El tema del cuerpo grotesco (central en el carnaval) sirve aquí a otro propósito: la monstruosidad permite imponer la seriedad unilateral. Es

${ }^{8}$ El lector debe concluir que pienso en particular en el empleo que hace Quevedo del carnaval, véase el libro de Edmond Cros 1988: 72-74. 
ésta una carnivalización que destierra la risa e impone la seriedad rigurosa de la moral y la didáctica. Cada una de las imágenes está subordinada a este sentido único y refleja la concepción unitaria del mundo. En este conjunto, las imágenes no son ambivalentes; la lógica unitaria subordina el nuevo mundo al viejo en el sentido único de las deformidades y órganos de los corporalmente "inferiores".

Se destacan y estereotipan las protuberancias del cuerpo desnudo del Otro (esta representación proviene de la formación ideológica práctica, se podría decir), mediante una tradición de clichés y normas, en contraste con el cuerpo vestido y virtuoso del conquistador, que adquiere así el status de uno de los universales. Al mismo tiempo, se conjura el pasado (la unidad de los fieles y la unidad de la Corona), para silenciar la heteroglosia, que de aceptarse, significaría una disrupción de la autoridad. Equivale a una especie de grado cero dialógico, ya que este silencio iba encaminado a suprimir la poliglosia activa del mundo nuevo. No hemos de olvidar que Colón llevó interpretes versados en el árabe como traductores (mediadores) de las nuevas lenguas nativas, que nada tenían que ver con las raíces de las distintas lenguas conocidas. ¿Hemos de extrañarnos de los giros orientales para nombrar los nuevos espacios?

Las cartas colombinas se pueden también relacionar con la épica, en su universo de traslaciones al pasado (el paraíso bíblico, el jardín de Edén, lo adánico, el mito de la edad dorada), mientras en un plano específico, el cronotopo del carnaval permite familiarizar los objetos desfamiliares (el procedimiento es totalmente a la inversa del ostranenie de los formalistas). Reducido al máximo, el objeto desnudo no es solamente ridículo, sino "pecaminoso"; desmembrado, no es cómico (pensemos en el código maestro rabelesiano), sino que funciona como un objeto de análisis "científico", el transformar los objetos vivos en objetos inertes y muertos, para su disección. La representación que se presenta a los lectores está más cerca de "lo siniestro" freudiano, y se emplea crudamente para degradar, al saturarlo de referentes ideológicos precisos que lo determinan; la inversión histórica convierte el pasado en eterno y lo sitúa totalmente fuera del tiempo, de hecho se adhiere a lo "ya-dicho". Desde una óptica filosófica o epistemológica esta inversión histórica articula una especie de preconstruido o prefiguración que consiste en restituir unos "orígenes" que justifican los valores eternos (remito a Bajtin, "Formas del tiempo y cronotopos en la novela"). Desde el punto de vista de la estructura cultural, aspira a legitimar como paradigma una jerarquía de valores eternos para el estado provincialista.

Podríamos continuar esta línea de reflexión, pero por el momento para apoyar mi lectura se hace necesario recordar la morfología de las constantes semióticas de la serie carnavalizada que Bajtin describe. Los núcleos básicos son: 1) el cuerpo, anatomía y fisiología; 2) la ropa; 3) la comida; 4) la bebida; 5) la sexualidad; 6) la muerte; 7) lo bajo escatológico. Cada una, como es sabido, tiene su propia lógica y sus propios sistemas sígnicos dominantes. Cualquier lector medianamente informado de los textos colombinos y los de Américo Vespucio podrá reconocer que las representaciones estereotipadas se logran mediante el empleo de esta serie. El cuerpo del Otro, en su desnudez y rasgos anatómicos (protuberancias, o fealdad, o belleza), formas de comer, la sexualidad, la barbarie (la re-acentuación del mito del canibalismo) o violencia contra el enemigo o contra los miembros de la tribu, y costumbres o hábitos biológicos (la defecación o la orina) se convierten en importantes elementos de representación. El cuerpo se convierte en una 
vara concreta para establecer jerarquías que miden el peso y valor superior de la cultura del viejo mundo, mientras la disección carnavalesca proyecta la imagen grotesca (que carece de la función regeneradora del grotesco ambivalente del carnaval). El cuerpo es usado a manera de indicador ideológico o categoría de valor, y los ideologemas son objetos de representación dialogizada de la "palabra plena desde el punto de vista ideológico" (Bajtin, "La palabra en la novela" en 1989a: 150).

La inversión histórica concreta de la heteroglosia emancipatoria del carnaval se activa aquí para servir un horizonte conceptual socio-ideológico. El ideologema del cuerpo (en el sentido preciso en que he definido este término) se precisa como la manifestación más acentuada del cierre de la diversidad en un marco monológico, encarcelándolo "en el interior de un sólo contexto" (1989b: 92; interpreto a Bajtin en otra dirección). Se monologizó la heteroglosia en el proceso de centralización sociopolítica y cultural. La retórica de la Iglesia inquisitorial con "su lenguaje único de verdad" sirvió no sólo para dominar el lenguaje del Otro, sino simultáneamente para legitimar con la palabra cualitativamente verdadera, la incorporación de los bárbaros a una uniformidad lingüística, cultural y de la verdad. Sobre esta base de imágenes desproporcionales del Otro, que se oponen intencionadamente a la la grandeza de la concepción político-religiosa del conquistador, lo grande se simboliza en contraste con lo pequeño, lo poderoso por medio de lo débil e impotente, la eternidad por medio de la exclusión. Todo lo que no es positivo desde el punto de vista cualitativo es bárbaro, deplorable e impotente, debe ser eliminado, y no puede oponerse a su desaparición.

Podríamos seguir esta línea argumental sobre el cronotopo rabelesiano, y concluir que mediante la óptica de la Iglesia inquisitorial, se invierte el carnaval socialmente, para canonizar un sistema ideológico cerrado. Como los cuerpos de los condenados que Foucault describe, los cuerpos grotescos de los "bárbaros" llevan inscritas las marcas de la licencia y pecaminosidad, y mediante la inversión socio-ideológica, las series del espíritu carnavalesco se invierten (en visión anatrópica) para representar los siete pecados capitales. La casa del tesoro de las imágenes del carnaval se convierte en su opuesto en el campo de la representación. El mundo conocido del carnaval medieval transgresor se convierte en una especie de frontera, proyectado desde una perspectiva ético-religiosa, y re-acentuado desde la perspectiva ideológica de la unificación. Por tanto, la serie carnavalizada adquiere nuevos significados y funciones en esta re-acentuación para imponer la verdad absoluta que había triunfado en Granada.

Pues bien, si los textos culturales son autónomos de la realidad referencial, el sentido figurativo del texto proyecta una ambivalencia en sentido ideológico. Si prestamos atención al contenido aquí, la inversión socio-política a la cual he aludido refracta otras esferas ideológicas (ética, epistemología, doctrinas políticas, religión). El sentido figurado refleja la totalidad del horizonte ideológico del cual forma parte, al mismo tiempo, el lenguaje figurado es ambivalente, ya que las series son tanto carnavalescas cuanto íconos de los siete pecados capitales. Para ampliar el problema de la ideología como signo ambivalente, se hace necesario volver a Bajtin.

Uno de los primeros rasgos de la ambivalencia es que las imágenes pueden siempre verse "al revés"; el rey destronado puede transformarse en esclavo, o el elogio en injuria, y la risa (base del carnaval), destrona el tono unilateral de la seriedad, del providencialismo 
y del pecado. El reino utópico de la abundancia, la victoria de la profusión universal de los bienes materiales, de la libertad, la igualdad y la fraternidad se garantiza mediante el triunfo del porvenir, de lo nuevo y mejor, sin lugar para el miedo (1989b: 230). El empleo de la serie (como en Rabelais, si bien no es el único), se asocia a una postura ética de la vida social, en contraste con los valores abstractos y universales. Lo que Nietszche llamó "la transvaluación de todo valor" es, en definitiva, el código maestro de la sociedad (europea occidental) centrada en oposiciones binarias teocéntricas, asimiladas como juicios de valor -bueno y malo, cristiano y pagano, con alma o sin ella.

Como formación discursiva emergente, el imperialismo (en lo político) y el capitalismo (en lo económico), se inscriben en el texto cultural colombino, en su interpelación de las riquezas materiales y la religión, combinando así en una unidad dos discursos aparentemente contradictorios y divergentes. Lo que nos importa subrayar de esta práctica es el empleo de los múltiples niveles de las operaciones del poder en la práctica de la escritura. Escribe en el estilo retórico y elevado de la época para sus reales y poderosos interlocutores; son palabras librescas perfectamente fieles ante la Iglesia, palabras subordinadas a las reglas verbales oficiales, a las convenciones. El tono y el estilo han salido del universo verbal del lenguaje oficial; incluso se podría decir que los tropos, la retórica y los cronotopos se reapropian (en el sentido bajtiniano de lucha por el signo y de re-evaluación) como principios constitutivos. Todo es ambivalente (hasta los nombres poseen un matiz elogioso/injurioso), pero es una ambivalencia sin el efecto cómico de la risa carnavalesca, sino con el tono serio de quien irá justificando el derecho de principio que tenían los soberanos y los pueblos para hacer la guerra, al establecer una distinción entre guerras injustas y guerras justas, mediante una representación axiológica no sólo incompleta, sino deformada.

Estas apropiaciones tan someramente mencionadas (el cronotopo carnavalesco en particular) se podrían leer como punto de intersección entre una retórica apocalítpica y el potencial emancipatorio de la carnavalización, que se convierte en su envés. De manera muy específica, se subvierte este lenguaje y se modifica y silencia para acoplarse a una atmósfera que podríamos denominar breuguelesca y dureriana de la retórica de derecho a la conquista, mediante el empleo de la palabra sagrada y autoritaria, con su carácter incuestionable y absoluto. "La violencia no conoce la risa" (dice Bajtin 1985: 356), y silenciarla, en el sistema de apropiaciones que he sugerido, hace que lo corporal se convierta en pathos. Forma parte de lo que podríamos llamar la "cultura de los medios" (inspirándome en Bajtin).

Conviene ahora retomar a Bajtin, que distingue con precisión entre el silencio y el sonido, la percepción del sonido sobre el fondo del silencio y el silencio y la taciturnidad, o ausencia de palabra (1985: 355-56). En este texto, Bajtin establece las condiciones de percepción del sonido, las condiciones de comprensión-reconocimiento del signo, y las condiciones para la comprensión semantizada de la palabras. La dos primeras indican que la percepción del sonido y la identificación del signo, forman parte del silencio. El silencio permite percibir el sonido y los distintos trazos del lenguaje (fonemas), y de ahí la comprensión y el reconocimiento de los elementos del discurso que forman parte del lenguaje, a los niveles fonológico, sintáctico y semántico. El silencio es el mundo nohumano, y se impone para obligar a otros a hablar de acuerdo con una lógica; el silencio es el espacio de las identidades, de las totalidades, del monologismo, de la univocidad, de la 
homologación. En contraste, el sonido es el espacio de la alteridad, de la plurivocalidad y del plurilingüismo, del diálogo. Es el espacio de lo vocativo, de la iconocidad del rostro del Otro, que pone en crisis las convenciones simbólicas y las restricciones indicativas del signo. Es el lugar de la ironía, de la parodia, de la risa; mientras el silencio es el lugar de la violencia, y pertenece a la cultura de los medios o razón-instrumental. ${ }^{9}$

La naturaleza socioeconómica y monológica del silencio, su voluntad de acotar la palabra, imponiéndole todos los acentos y significados jerárquicos, forma parte de esa fábula convertida en verdad inaugurada en esta coyuntura de la modernidad en expansión imperialista. La lógica cultural de esta modernidad permite construir un discurso que se apropie del pasado (todos los textos maestros del pasado, desde la Biblia hasta el Imperio Romano) en términos de espacio para el desarrollo imperial, otra forma de llamar a la expansión europea de mercados. Lo que intento decir (re-evaluando a Nietzsche) es que los textos culturales a que he aludido se pueden leer como instancia discursiva que reduce el mundo desconocido a la interpretación, donde todo evento es interpretación, y la interpretación es a su vez el único acontecimiento, lo único que sucede. Así pues, se podría pensar que se aspira a establecer lo histórico como proceso de interpretación que no vacilaría en definir como ideológico o mitológico. En todo caso, estamos en la esfera del tono unilateralmente serio, en el lugar del patetismo.

Si mi hipótesis general se acepta, conviene ahora establecer algunas analogías entre este "silencio" bajtiniano y "el cuerpo de los condenados" a que alude Foucault. ${ }^{10} \mathrm{La}$ brutalización del cuerpo, primero se silencia llamando a los indígenas bruta animalia, y luego se focaliza como disciplina y coerción; se le produce un alma al cuerpo deformado, para así utilizarlo funcionalmente. Se recordará que es deforme, porque no está equilibrado, sino que se ha desarrollado inarmónicamente en sus distintas facultades. Quizá no resulte excesivo leer en la representación fluctuante del cuerpo la división del trabajo, una de las especificaciones de esta forma de estructurar la historia según supremacías y subordinaciones. La "anatomía política" (en frase de Foucault) es el medio para hacer funcionar las fuerzas coercitivas, que hasta la fecha se adscriben a la sociedad moderna que surgió a partir del siglo XVIII con la "razón instrumental". Planteado así, el problema del pasado significado en la fecha coyuntural de 1492 se presenta, en el aspecto del contenido y de la forma, como el problema de la autoridad y del dominio. Mi forma de retomar y utilizar el concepto "razón instrumental" para ilustrar la cadena de interpretaciones en su conjunto, permite ahora afirmar que en esta coyuntura el cuerpo fue un intermediario o mediador para justificar no sólo que el Otro careciera de alma, sino para negarle un lugar en el cuerpo místico de la Iglesia. Privar a los condenados de "alma" e inscribirles los cuerpos con los siete pecados capitales (inversión de las siete series carnavalizadas), ofreció un apoyo teológico para justificar el poder absoluto de la ratio occidental en esta totalización cristiana (católica) imperial del mundo conocido. El Tratado de Tordesillas sellará este pacto fantasmático para establecer el dominio.

\footnotetext{
${ }^{9}$ Kierkegaard, teórico de la palabra indirecta, escribe que la palabra directa no se preocupa por la alteridad, sino que intenta suprimirla, asimilarla. Esta palabra no constituye comunicación, solo comunicación en silencio. Augusto Ponzio, 1982, ha visto con claridad este punto.

${ }^{10}$ Aludo específicamente a Vigilar y castigar, 1978, consciente de mi apropiación crítica, al intentar releer la historia de esta modernidad y su razón instrumental.
} 
Inscrito con los siete pecados capitales de acuerdo a una compleja red de relaciones recíprocas (una especie de mutuo reflejo de las instituciones que he mencionado), el cuerpo se somete a las relaciones de poder y dominio. Constituido como fuerza de trabajo, es "tanto un cuerpo productivo cuanto un cuerpo sometido" (Foucault 1978: 109-129). Su potencial económico y político se unifica mediante la violencia y el sometimiento en el camino de la moral cristiana. El cuerpo desnudo, inscrito con las deformidades de los siete pecados capitales, era sospechoso de enfermedades morales, tal la posesión demoníaca o la brujería. Finalmente, este cuerpo sometido y silenciado, termina leyéndose a través del texto maestro de la tradición judeo-cristiana y todo el conocimiento científico disponible, se pone al servicio de lo teológico-inquisitorial mediante su serie de "expertos" que construyen un discurso sobre su identidad trasladado del modelo de supremacías.

Planteado así, el conflicto entre el cuerpo y el alma (dramatizado por Eurípides, que desarrolló los nexos entre el impulso sexual y el apetito) da lugar a los fundamentos dualistas del ascetismo en su forma plena. Quizás la novedad de la forma de este dominio sea que puesto que para el cristianismo el cuerpo impide la libertad del alma, actuando como la prisión del espíritu, los cuerpos de los condenados del nuevo mundo jamás podrían desatarse de las cadenas de los apetitos, ya que carecían de alma. Sus cuerpos por definición aprisionaban el espíritu. Como se ve, el carácter imperativo de la moral (recordando los imperativos kantianos) crea una de las grandes construcciones teológicas, constitucionales y éticas del mundo moderno, ya que el fervor evangélico justificaba la intolerancia. El predominio de este imperativo moral transformó a todo conquistador en teólogo, pues no era necesario estudio alguno para concentrarse en la "anatomía política", convirtiendo el cuerpo de los condenados en expresión del pecado y de la herejía demoníaca. Digamos que se le adscribe a los indígenas posiciones de sujeto cambiantes en una típica petición de principio.

Si en la famosa Carta del Descubrimiento enviada a Luis de Santángel el 15 de febrero de 1493 (muy parecida a la enviada a los reyes el 4 de marzo), los cuerpos son signo ambivalente y objeto de curiosidad, en correlación con las luchas que surgieron en la zona se va construyendo otra representación o posición de sujeto, y la imagen paradisíaca de simplicidad y bondad da lugar a una tecnología corporal y a la reificación y fetichización de la bruta animalia carente de alma (compárese con las anotaciones en el Diario, si bien es sabido que el texto es "obra" de Las Casas, Zamoral [1993] indica con perspicacia los problemas de autoría). El cuerpo silenciado connota y condensa el texto maestro de la modernidad; la imposición de instituciones e ideas, de tecnologías y culturas facilitó la acumulación de riquezas que a su vez permitió construir la civilización occidental. La carnavalización (tal y como he sugerido) fue el punto nodal de ambivalencia y proliferación discursiva, y podemos entenderlo como formas de articulación hegemónica en el proceso de la construcción de identidades funcionalizadas en el sentido de la utilidad social: tanto la identidad colonial cuanto el imaginario colonialista. Ambos se consideraban construcciones finalizadas en el sistema monológico cerrado.

Esta construcción es, en cierto sentido, el hecho histórico que simultáneamente unía y separaba a ambos. La cultura de los medios que he descrito, y las formas simbólicas en que se expresaron en 1492-1493 puede interpretarse en el presente como un sistema de significados compartidos, que une tanto al sujeto subalterno como al sujeto opresor. Dicho 
de otra manera, nos revela la ambivalencia y posibilidad de inversión y subversión de cualquier construcción histórica.

Las construcciones creadas en esta coyuntura — superioridad europea/inferioridad del indio, entre múltiples núcleos de oposiciones axiológicas - persiste hasta el presente. Se han re-acentuado, y las imágenes acumulan una forma de comprensión del mundo, un habitus, una interpretación portadora de contenidos, en cuya base se encuentra el establecimiento del dominio y una reducción a papeles fijos e infranqueables en la vida social.

Pero no hay enunciados aislados; las palabras, sin embargo, recuerdan su pasado (son "auráticas" decía Walter Benjamin), y connotan y denotan en otros núcleos semánticos, donde adquieren posibilidades de contactos y combinaciones. En el proceso de lucha contra la palabra de fronteras consagradas e inexpugnables se ha ido formando el discurso anticolonialista y de afirmación propia. No resulta difícil entender la diferencia entre los sujetos e identidades silenciados y ficcionalizados mediante la estructura de dominio, y el "yo" colectivo de una Rigoberta Menchú, por ejemplo, construido al margen y fuera de las fronteras de las ontologías europeas."

Esta concepción de sujeto colectivo estuvo silenciado hasta la emergencia y el acceso a la historia escrita; sin embargo, es imposible reducir tal subjetividad ni al sujeto occidental, ni al sujeto empírico y racional cartesiano. Construido fuera y en lucha contra esta historia de la conquista y de las hegemonías instauradas entre 1492-1493, este "yo" no es sólo colectivo, sino un yo fuera de las instituciones occidentales, en pugna con ellas, con su propio espacio discursivo, con su propia elaboración semiótica. ${ }^{12}$

Aquella red ideológica que intentó articular el mundo moral en torno a las nociones de culpa y castigo, jerarquías nacidas dentro del cuadro fundado en la originaria división entre fuertes y débiles inaugurada en 1492, se ha transformado, si bien permanece en el diálogo que continúa. Ambas construcciones sociales - colonizador y colonizado o sujeto occidental y su Otro - se han transformado en su contrario mediante una lógica de suplementariedad y el proceso natural de erosión y desintegración de toda categoría. El proyecto de dominio imperial y desarrollo que llevó a la conquista, a su vez producto de una crisis, ha sido el punto de partida para refutaciones, respuestas y polémicas. El discurso colombino que nos ha permitido esta extensa reflexión, destinado a verdades conceptuales a través de un sistema de símbolos tendencialmente unívocos, es, como todo enunciado, excéntrico. Todo esto, sin bien plantea dificultades, impide que el discurso se reduzca simplemente, pues si bien emblemático de una forma de exclusión encaminada a convertir la fábula en verdad con el fin de desarrollar y consolidar el dominio, tiene una grandísima importancia para todo pensamiento que se plantee la renovación radical. Se puede decir que ofrece un sólido marco narrativo para problematizar nuevos modos de organización, que nos permitan aproximarnos a nuestra experiencia posmoderna. Las Cartas y toda la formación que ayudaron a crear dejaron abiertas un conjunto de cuestiones, de cuya respuesta reponsable depende el porvenir.

"Tomo en cuenta las observacionesde Albert Memmi 1979 en torno a la dependencia, el racismo y la dominación. Véase Elbaz 1988.

${ }^{12}$ En este sentido muy preciso, coincide con el sujeto de magreb que Robert Elbaz 1988 ha analizado. 


\section{REFERENCIAS BIBLIOGRÁFICAS}

Bajtin, Mijail. Estética de la creación verbal. México: Siglo XXI, 1985.

La cultura popular en la Edad Media y el Renacimiento. El contexto de Francois Rabelais. Madrid: Alianza, 1989.

Teoría y estética de la novela. Madrid: Taurus, 1989.

P. N. Medvedev (M. Bajtin). El método formal en los estudios literarios (Introducción crítica a una poética sociológica). Madrid: Alianza, 1994.

Barthes, Roland. Mythologies. París: Seuil, 1957.

Cros, Edmond. Theory and Practice of Sociocriticism. Minneapolis: The University of Minnesota Press, 1988.

During, Simon. "Waiting for the Post: Some Relations Between Modernity, Colonization and Writing". Theo d'Haen y Hans Bertens, editores. History and Post-War Writing. Postmodern Studies 3. Amsterdam: Rodopi, 1990. 249-310.

Elbaz, Robert. Le discours maghrébien. Dynamique textuelle chez Albert Memmi. Montréale: Le Préambule, 1988.

Foucault, Michel. Vigilar y castigar. Nacimiento de la prisión. (1975) Madrid: Siglo XXI, 1978. $3^{\mathrm{a}}$ edición.

Kamen, Richard. The Spanish Inquisition. New York: Mentor, 1965.

Klossowski, Pierre. The Baphomet. Nueva York: Eridanos Library, 1988.

Memmi, Albert. Portrait du colonisé précedé du portrait du colonisateur. Paris: Payot, 1979.

Montrose, Louis. "The Work of Gender in t Discovery". Representations 33 (1991): 141.

Nietzsche, Federico, Hans Vaihinger. Sobre verdad y mentira. Madrid: Tecnos, 1990.

Ponzio, Augusto. "La palionimia in Soren Kierkegaard". Polifonie. A. Ponzio, editor. Bari: Adriatica, 1982. 11-30.

Rodríguez Monroy, Amalia. "De la palabra y su fiesta de resurrección. Problemas de una poética formal". Medvedev (Bajtin), El método formal, 1994.

Wodak, Ruth, editora. Language, Power and Ideology. Studies in Political Discourse. Amsterdam: John Benjamins, 1989.

Zamora, Margarita. Reading Columbus. University of California Press, 1993.

Zavala, Iris M. "El discurso canibalístico sobre el Nuevo Mundo". Acta Poética 12 (1991): 5-36.

"Notes on the Cannibalistic Discourse of Monology". David Shepherd, editor. Bakhtin: Carnival and Other Subjects, Critical Studies 3:2-4:1/2 (1993): 277-294. 